\title{
GEOGRAFIJA IN EVROPSKE RAZVOJNE SMERNICE IZOBRAŽEVALNE IN RAZISKOVALNE DEJAVNOSTI
}

\author{
dr. Lučka Lorber \\ Oddelek za geografijo, Filozofska fakulteta Univerze v Mariboru \\ Koroška cesta 160, SI-2000 Maribor \\ e-mail: lucka.lorber@uni-mb.si
}

Strokovni članek

COBISS 1.04

\section{Izvleček}

Posodobitev evropskih univerz, ki zajema njihove medsebojno povezane vloge izobraževanja, raziskav in inovacij, velja za temeljni pogoj uspeha lizbonske strategije, obenem pa tudi za del širšega približevanja k svetovnemu in na znanju temelječemu gospodarstvu. S svojim prispevkom želim opozoriti na evropske razvojne smernice, izobraževalne in raziskovalne dejavnosti v odnosu do prihodnjega razvoja geografske stroke in položaja geografske vede v Republiki Sloveniji.

Ključne besede: poslanstvo univerz, kakovost visokošolske dejavnosti, institucionalna prenova, mreženje, študij geografije

\section{GEOGRAPHY AND EUROPEAN DEVELOPMENT TRENDS IN EDUCATION AND RESEARCH}

\begin{abstract}
Modernization of European universities, which includes their inter-related roles of education, research and innovation, is considered the fundamental requirement for the success of the Lisbon Strategy, and at the same time, a wider approximation to the global- and knowledge based economy. This contribution aims at drawing attention to the European development guidelines and educational and research activities in relation to future development of geography discipline and the position of geography as a science in the Republic of Slovenia.
\end{abstract}

Key words: mission of the universities, quality of higher education activity, institutional adaptation, network, geography studies 


\section{UVOD}

$\mathrm{V}$ zadnjem desetletju potekajo $\mathrm{v}$ evropskem prostoru intenzivne razprave o posodobitvi evropskih univerz, tako z državami članicami kot akademskimi in znanstvenimi združenji. Evropska razsežnost ponuja možnosti širšega delovanja, večjo raznolikost in intelektualno bogastvo virov ter priložnost za sodelovanje med ustanovami. Ob temeljnih lokalnih, regionalnih in nacionalnih koreninah univerz postaja krepitev družbene vloge univerz $\mathrm{v}$ kulturno in jezikovno raznovrstni Evropi vedno pomembnejša.

S 4000 ustanovami, z več kot 17 milijoni študentov in okrog 1,5 milijonov osebja, med katerimi je 435.000 raziskovalcev, imajo evropske univerze ogromen potencial, ki pa ni v celoti izkoriščen in učinkovito uporabljen, da bi podprl cilje Lizbonske strategije ter ustavil proces zaostajanja $v$ svetovni konkurenci na področju izobraževanja, raziskav in inovacij. Da bi države članice dosegle postavljene cilje, morajo ustvariti potrebne pogoje, ki bodo univerzam omogočali, da uspešno izpeljejo posodobitev sistema, ki jim bo omogočal sodelovanje pri ustvarjanju na znanju temelječe družbe.

Slovenija, tako kot druge članice Evropske unije, visoko vrednoti svoje univerze, vendar jih poskuša ohranjati na nacionalni ravni s podrobnimi predpisi glede organizacije, nadzora, mikromanagementa in zuvajanjem nezaželene stopnje enotnosti (File in Goedegebuure 2003). To je pripeljalo do oblikovanja skupnega nacionalnega visokošolskega sistema, ki je otežil oz. preprečil razširitev mednarodne ponudbe sodelovanja in osredotočenje na kakovost.

Slovenske univerze ponujajo enake programe študentskim skupinam, ki so bile izbrane z istim postopkom izbirnosti, niso pa odprte za druge vrste učenja in druge učence, npr. nediplomske programe prešolanja za odrasle ali premostitvene programe za študente, ki se niso šolali po tradicionalni poti. Poleg tega upravni predpisi še vedno ovirajo akademsko mobilnost za študij, raziskovalno usposabljanje ali delo v drugi državi. Medtem ko imajo vse ustanove nekatere skupne vrednote in naloge, ne potrebujejo vse enakega ravnovesja med izobraževanjem in raziskavami, istega pristopa $\mathrm{k}$ raziskavam in raziskovalnemu usposabljanju ali enakega spleta storitev in akademskih disciplin.

Univerze in raziskovalci morajo prav tako sprejeti dejstvo, da raziskovanje ni več osamljena dejavnost, in da se poudarek s posameznih raziskovalcev premika na skupine raziskovalcev in globalne raziskovalne mreže (Jenniskens 2001). Pri prenosu znanstvenih spoznanj v prakso je potrebno izhajati iz celotnega kompleksa ekonomskih, družbenih in ekoloških razmer razvoja. V novih oblikah proizvodnje (znanstvenega védenja), ki se je v devetdesetih letih uveljavila v znanstveno in tehnološko razvitih deželah, je ključnega pomena ravno aplikativno-razvojna vloga znanosti (Mali 1995). Prenos védenja (knowledge transfer) se iz akademskih oziroma drugih neindustrijskih institucij prenaša $\mathrm{v}$ industrijski sektor kot model omrežij. Na ta način ne gre več za enosmerni potek od temeljnega $\mathrm{k}$ uporabnemu znanju, od raziskovanja k razvoju, temveč za vsakokratno prepletanje različnih dejavnikov (Lorber 2003a).

Znanstveni problemi pogosto presegajo tradicionalne disciplinarne strukture: najmodernejše raziskave se vedno pogosteje opravljajo na presečišču akademskih disciplin ali v multidisciplinarnih okoljih. Raziskovalno okolje univerz je bolj konkurenčno in globalizirano ter zahteva večje vzajemno delovanje (Jongbloed, Maassen in Neave 1999). 
V okviru akademske skupnosti je še vedno podcenjeno in neustrezno akademsko vrednoteno raziskovanje in izmenjava znanj z gospodarstvom in družbo. Prenos znanja ima prešibke učinke na gospodarski in družbeni razvoj, raziskovalci z doktoratom ostajajo $\mathrm{v}$ akademskih krogih na univerzi in ne nadaljujejo svoje poklicne poti v določenih gospodarskih panogah in v podjetništvu (Clark 1998).

Velik problem v Sloveniji predstavlja tudi sistem dvojnega financiranja, ki vpliva tako na izobraževanje kot na raziskovanje. Prav tako država ni zagotovila ustreznega financiranja visokošolskega sistema, ni uspela uskladiti razmerja med številom študentskih vpisov in rastjo javnih sredstev ter nadomestiti razlike iz zasebnih virov. V prihodnje bo treba vse večji delež sredstev, potrebnih za izvajanje raziskovalnega in izobraževalnega programa, pridobiti iz nejavnih virov (Lorber 2009b).

\section{GEOGRAFSKI ŠTUDIJ NA SLOVENSKIH UNIVERZAH}

Oddelki za geografijo v Ljubljani, Mariboru in Kopru se ločijo med seboj tako po starosti kot po velikosti in študijskem ter raziskovalnem programu. Kljub temu je nacionalna visokošolska zakonodaja definirala sistem, ki je vzpostavil za vse oddelke enake pogoje delovanja in zagotovil kontinuiteto akademskega dela ob spoštovanju splošno veljavnih akademskih pravil.

Univerzitetni študij geografije ponuja različne dvodisciplinarne pedagoške študijske programe in enodisciplinarne študijske programe geografije. Razvoj geografskega študija ima osrednjo vlogo pri vzgoji in izobraževanju geografov v slovenskem prostoru.

Bolonjska prenova študijskih programov in uvedba tristopenjskega študija je priložnost, da slovenski geografi ponudimo trgu širši izbor aktualnih predmetov in izbirnost ne samo programov, temveč tudi dele posameznih programov tako v nacionalnem kot mednarodnem prostoru.

Slika 1: Shematski osnovni opis študijskega modela

Figure 1: Schematic depiction of model underlying the study

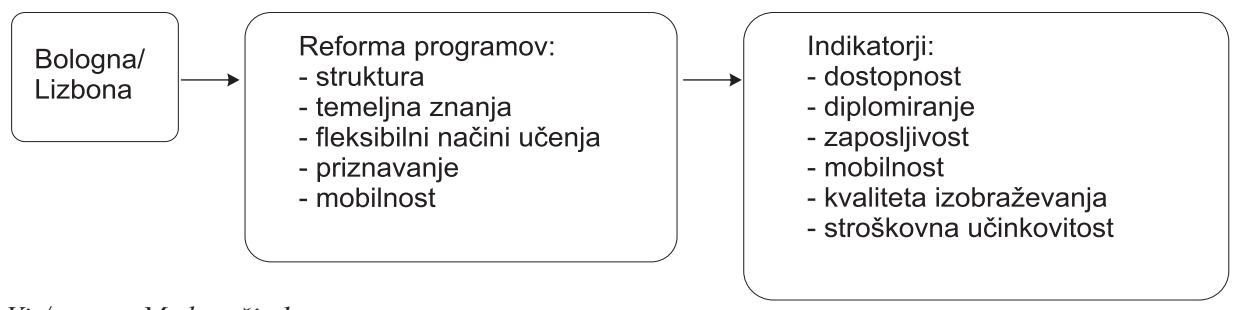

Vir/source: Medmrežje 1 .

Raziskovalno delo oddelkov poteka v okviru nacionalnega razvojnega in raziskovalnega programa ter mednarodnih raziskovalnih projektov. Individualno raziskovalno delo se premika na skupine raziskovalcev in raziskovalne mreže. To povezovanje narekuje tudi značaj raziskav, saj znanstveni problemi pogosto presegajo tradicionalne disciplinarne strukture. 
Tudi geografska stroka se zaveda, da se najmodernejše raziskave vedno pogosteje opravljajo na presečišču akademskih disciplin ali v multidisciplinarnih okoljih. Raziskovalno okolje univerz je vse bolj konkurenčno in globalizirano ter zahteva vzajemno sodelovanje (Lorber 2009a).

Povezovanje z gospodarstvom in institucijami iz neposrednega okolja je bilo prisotno, čeprav se še vedno podcenjujejo možne ugodnosti izmenjave znanja z gospodarstvom in družbo. Posamezne javne institucije in tudi gospodarska podjetja še niso razvila zadostnih absorbcijskih zmogljivosti za zaposlovanje geografov in prenos uporabnega znanja, ki ga nudijo raziskave (Lorber 2003b).

Financiranje geografskih oddelkov je urejeno s sistemom javnega financiranja. V prihodnje bo treba pomanjkanje sredstev za dejavnost tako raziskav kot izobraževanja nadomestiti z dejavnostjo na trgu.

\section{EVROPSKE SMERNICE VISOKOŠOLSKEGA RAZVOJA V NOVEM DESETLETJU}

Ministri, pristojni za visoko šolstvo v 46 državah bolonjskega procesa, so na srečanju v Leuvenu aprila 2009 določili prednostne naloge evropskega visokošolskega prostora za naslednje desetletje.

Prva prioriteta je uresničevanje procesa Evropa znanja - visoko ustvarjalnega in inovativnega znanja za potrebe vseživljenjskega učenja in čim širše vključenosti visokega šolstva.

Drugi cilj se nanaša na izzive globalizacije in pospešen tehnološki razvoj, ki terjata od visokošolskih institucij razvijanje kompetenc znanja, ki jih diplomanti potrebujejo na spreminjajočem se trgu dela.

Prav tako je cilj, da si bo evropsko visoko šolstvo za zagotavljanje vzdržnega gospodarskega razvoja prizadevalo za inovacije, ki bodo temeljile na povezovanju izobraževanja in raziskovanja na vseh ravneh. S tem bi naj dosegli tudi kulturni dialog, socialno strpnost in varnost evropskega prostora. Javne investicije v visoko šolstvo so najvišja prednostna naloga.

Visoko šolstvo ostaja javna odgovornost, kjer se morajo visokošolske institucije odzvati na potrebe družbe ob spoštovanju evropskih vrednot, kot so institucionalna avtonomija, akademska svoboda in družbena pravičnost (Medmrežje 2).

\section{PRILAGAJANJE ODDELKA ZA GEOGRAFIJO FILOZOFSKE FAKULTETE UNIVERZE V MARIBORU NOVIM IZZIVOM}

Oddelek za geografijo Filozofske fakultete Univerze v Mariboru ${ }^{1}$ je sledil navodilom preoblikovanja študija geografije glede strukture in dolžine študijskih programov, vendar

\footnotetext{
${ }^{1}$ Oddelek za geografijo Univerze v Mariboru je bil ustanovljen na Pedagoški akademiji leta 1961. Akademija se je preimenovala v Pedagoško fakulteto leta 1985. Filozofska fakulteta Univerze v Mariboru, kamor danes sodi Oddelek za geografijo, je nastala s preoblikovanjem Pedagoške fakultete leta 2006. Na Oddelku za geografijo je
} 
to samo po sebi ne ustvarja pogojev za namen bolonjskega procesa. Veliko truda bo potrebno, da bi uresničili temeljne cilje bolonjske reforme glede usklajenosti kompetenc znanja s pričakovanji zaposlitvenega trga in zanesljivega sistema zagotavljanja kakovosti izobraževalne ter raziskovalne dejavnosti. Torej, potrebno bo veliko več kot le doseganje skladnosti s standardi. Učni načrti so sicer prenovljeni in temeljijo na primerih dobrih praks doma in v tujini, vendar niso dani ustrezni kadrovski in materialni pogoji za primerljivo, kakovostno izvedbo programov.

V študijskem letu 2008/09 se je pričel izvajati novi bolonjski univerzitetni dvodisciplinarni študijski program prve stopnje Geografija. Diplomanti bodo lahko v prihodnje svoje znanje nadgradili v dveh študijskih programih, ki so še v pripravi oz. v akreditacijskem postopku:

- dvodisciplinarni pedagoški študijski program druge stopnje Geografija;

- enodisciplinarni študijski program druge stopnje Regionalne in okoljske študije (delovni naslov);

- enodisciplinarni študijski program tretje stopnje Geografija.

V študijskem letu 2009/10 smo pristopili k pripravi in izvedbi dela skupnih magistrskih študijskih programov tujih univerz:

- The EU and the Western Balkans: the socio-economic outlook skupnega študijskega programa Master in European Studies (Siena, Salamanca, Coimbra, Strasbourg, Krakov, Atene, Hannover, Oradea, Montpellier);

- Euromediterranean Master in Culture and Tourism (Jean Monnet Euromediterranean Centre of Excelence, University of Bari).

V okviru evropskih programov mobilnosti Erasmus in CEEPUS (Central European Exchange Programme for University Studies) potekajo izmenjave študentov ter visokošolskih učiteljev in asistentov. Oddelek za geografijo Filozofske fakultete Univerze v Mariboru je koordinator CEEPUS mreže GeoRegNet, ki povezuje sedemnajst univerzitetnih geografskih oddelkov iz desetih držav in omogoča partnersko sodelovanje. V okviru mreže potekajo semestrske izmenjave študentov, gostujoča predavanja profesorjev, bilateralni projekti, promocija raziskovalnega dela in organizacija poletnih šol GeoRegNet (Evropa regij-Evropa kot regija, poletna šola v Mariboru septembra 2008; poletna šola v Olomoucu avgusta 2010). $\mathrm{Z}$ razvojem mreže so bili podpisani bilateralni meduniverzitetni sporazumi, s katerimi so ustvarjeni pogoji za poglobljeno mednarodno sodelovanje pri pripravi skupnih študijskih programov in raziskovalnih projektov.

$\mathrm{Na}$ oddelku bo treba povečati študentsko in profesorsko mobilnost. Delež diplomantov in raziskovalcev, ki bodo najmanj en semester študirali v tujini, naj bi se podvojil. Vse oblike mobilnosti predstavljajo obogatitev študijev na vseh ravneh ter obenem dejavnik izboljšanja poklicnega napredovanja univerzitetnih raziskovalcev in sodelavcev (Lorber 2008).

Znanstvenoraziskovalna dejavnost članov Oddelka je bila do začetka devetdesetih let prejšnjega stoletja usmerjena predvsem v agrarno in regionalno geografijo ter preučevanje

zaposlenih šest visokošolskih učiteljev in dve asistentki. V študijskem letu 2009/10 je bilo v prvi letnik vpisanih 64 rednih in 6 izrednih študentov. 
obmejnih območij v severovzhodni Sloveniji. Danes se je raziskovalno področje uspešno razširilo, razvijajo se tudi aplikativne študije, povezane z regionalnim razvojem.

Raziskovalni progam bo treba oblikovati v skladu z evropskimi smernicami znanstvenih raziskav. V prihodnje se je treba osredotočiti manj na znanstvene discipline in bolj na področja raziskav ter doseči vzajemno delovanje med študenti, raziskovalci in skupinami raziskovalcev z večjo mobilnostjo med disciplinami, sektorji in raziskovalnimi okolji. Ta pristop zahteva spremembe tako pri merilih vrednotenja raziskovalnega dela kot pri raziskovalnem usposabljanju in izvedbi doktorskega študija.

Raziskovalno delo je dobilo nove možnosti razvoja s sodelovanjem v interdisciplinarni programski skupini z raziskovalnim programom Slovenska identiteta in kulturna zavest $\mathrm{v}$ jezikovno in etnično stičnih prostorih $\mathrm{v}$ preteklosti in sedanjosti in $\mathrm{z}$ ustanovitvijo Mednarodnega centra za ekoremediacije (ERM Centre). Mednarodno in nacionalno znanstvenoraziskovalno sodelovanje se je okrepilo tudi zustanovitvijo znanstvene periodične publikacije Revija za geografijo (Journal for Geography), katere prva številka je izšla leta 2006.

Tudi zato, da bi presegli trdovratno neusklajenost med usposobljenostjo diplomantov in potrebami delovnega trga ter ustvarili večje možnosti za zaposlitev, sodelujemo z lokalnimi skupnostmi, gospodarskimi družbami, regionalnimi agencijami in izobraževalnimi institucijami. Še posebej dejavno povezovanje in prenos znanja potekata na področju trajnostnega razvoja v okviru Mednarodnega centra za ekoremediacije. Center sledi evropski direktivi vzpostavljanja pogojev za oblikovanje inovativnih učnih načrtov, novih metod poučevanja in ponuja tako strokovne programe usposabljanja, povezane z opravljanjem poklica, kot podiplomske individualne programe, ki so vezani na raziskovalne projekte. S tem se spodbuja podjetniška miselnost med študenti in raziskovalci.

\section{SKLEP}

Prilagajanje geografskega študija na slovenskih univerzah evropskim razvojnim smernicam na področju izobraževalne in raziskovalne dejavnosti pomeni velik izziv. Posodobitev univerzitetnega študija terja tako programske kot institucionalne sistemske spremembe. Za uspešno izvajanje teh sprememb pa ni odgovorna le država, temveč tudi univerza. Država naj bi sprejela zakonske spremembe, ki bodo zagotovile fleksibilnost visokošolskega sistema in ustreznost enotnega načina financiranja izobraževalne in raziskovalne dejavnosti.

Univerze bodo morale uravnotežiti akademsko avtonomijo z družbeno odgovornostjo. Univerzitetna avtonomija tudi v bodoče pomeni avtonomijo profesorja pri njegovem delu in pravico študenta, da z znanjem pridobi ustrezno javno listino in kompetence znanja, ki mu omogočajo zaposlitev. Družbeno odgovorna univerza je aktivni člen v razvoju družbe, ki doseže svoj potencial in je enakopravni partner v mednarodni konkurenci ter ne zaostaja pri hitro spreminjajočih se raziskovalnih programih in študijskih programih, ki izhajajo iz družbenih potreb (Medmrežje 3).

Geografski oddelki na slovenskih univerzah čutijo prednosti in pomanjkljivosti bolonjske reforme, kakor je bila izvedena $\mathrm{v}$ nacionalnem prostoru. Medtem ko imajo geografski 
oddelki nekatere skupne akademske vrednote in obveznosti, pa imajo tudi različne danosti in možnosti izbora poti v prihodnosti. Slovenska geografija potrebuje programe odličnosti, visokokakovostno izobraževanje in raziskave, sodelovanje s svetovno znanimi raziskovalnimi središči in z mrežami odličnih nacionalnih ter regionalnih raziskovalnih institucij. Takšno razvojno smer je možno uresničiti z združevanjem znanja, raziskav in raziskovalnih potencialov, ki bi omogočili konkurenčnost in primerljivost z najboljšimi. Preseči bo treba individualnost in razdrobljenost ter si prizadevati za sodelovanje pri raziskavah, poučevanju in izvajanju storitev.

Slovenska geografija postaja globalno aktivna, sledi mednarodnim standardom kakovosti in si prizadeva z znanstvenimi referencami uvrstiti v svetovno priznane bibliografske baze. $\mathrm{S}$ partnerstvi na skupnih raziskovalnih projektih in doktorskih študijskih programih, z ustreznim deležem gostujočih profesorjev in mobilnostjo študentov bo omogočena strokovna medsebojna kontrola in dvig kakovosti (Lorber 2006a). Z nadaljnjim medinstitucionalnim in medregionalnim povezovanjem bo geografija ohranila status pomena nacionalne vede in bo nedeljivo sooblikovala razvoj geografije kot znanstvene discipline.

\section{Viri in literatura}

Clark, R. B. 1998: Creating entrepreneurial universities: organizational pathways of transformation. Pergamon, Oxford.

File, J., Goedegebuure, L. (ur.) 2003: Real time systems: reflections on higher education in the Czech Republic, Hungary, Poland and Slovenia. Center for higher education policy studies, CHEPS, Enschede.

Hudson, B., Zgaga, P. (ur.) 2008: Teacher education policy in Europe: a voice of higher education institutions. Umeå.

Jenniskens, I. (ur.) 2001: Management and decision-making in higher education institutions. LEMMA Publishers, Enschede.

Jongbloed, B., Maassen, P., Neave, G. 1999: From the eye of the storm: higher education's changing institution. Kluwer Academic Publishers, Dortrecht/Boston/London.

Lorber, L. 2003a: Transfer of know-how and technology-economy, region, university. Informatologia 36, 1. Zagreb.

Lorber, L. 2003b: Prenos znanja in tehnologij kot spodbujevalec regionalnega razvoja. Podravina 2, 3. Samobor.

Lorber, L. 2006a: Upravljanje: delavnica. V: Strokovni posvet Spremljanje in zagotavljanje kakovosti na Univerzi v Mariboru. Maribor.

Lorber, L. 2006b: Meaning of inclusion of the South East European higher education area in the formation of the European knowledge-based society. Keynote paper at the Rectors' and Students' Conference of South East Europe. Ljubljana.

Lorber, L. 2007: External institutional evaluation at the Faculty of Arts, University of Ljubljana. Guest presentation at the seminar Management in Higher Education, UP Faculty of Management Koper in collaboration with CHEPS (Center for Higher Education Policy Studies). Izola. 
Lorber, L. 2008: New challenges of geography in cultural and institutional association within the European higher education area. Revija za geografijo 1/3. Maribor.

Lorber, L. 2009a: Nove paradigme ekonomske geografije. Pozivno stručno predavanje na Zimskom seminaru za nastavnike geografije. Hrvatsko geografsko društvo, Zagreb.

Lorber, L. 2009b: System of financing higher education in Slovenia. Presentation from the TEMPUS Workshop Modernisation and reconstruction of University management and structure in Gent.

Majerhold, K. (ur.) 1999: Univerza pleše avtonomno? ŠOU in Zavod Radio študent, Ljubljana.

Mali, F. 1995: Aplikacija znanosti in prenos znanja v industrijo. Raziskovalec 25, 3. Ljubljana.

Neave, G. (ur.) 2000: Abiding issues, changing perspectives: visions of the university across a half-century. International Association of Universities, Paris.

Medmrežje 1: Schematic depiction of model underlying the study. http:/ec.europa.eu/ education/pdf/doc242_en.pdf(15.3.2010)

Medmrežje 2: The european higher education areas, Bologna process. http://www.ond. vlaanderen.be/hogeronderwijs/bologna/conference/documents/Leuven_Louvain-laNeuve_Communiqué_April_2009.pdf(15.3.2010)

Medmrežje 3: Nacionalni program visokega šolstva Republike Slovenije (NPVS). http:// www.uradni-list.si/1/content?id=35224 (15.3.2010)

\section{GEOGRAPHY AND EUROPEAN DEVELOPMENT TRENDS IN EDUCATION AND RESEARCH}

\section{Summary}

During the last decades, in most of the developed countries the reforms of higher-education systems occurred due to the result of global changes and development of market economy. The European higher education systems, which in the $19^{\text {th }}$ century strengthened the interests of the newly established countries, became rigid and their response to social needs was too slow; moreover, they were particularly unable to follow the needs of the labor market. Rapid economic development demanded mass higher-education training which in turn demanded a reform of the elitist university studies, previously intended for smaller groups.

Slovenian universities were being established due to national requirements in a particular time period, while later on, their programmes and institutional structures adapted in a more enterprising way and developed a closer cooperation with their respective regional, national and international environments. Although in the 'transition' years there was no clear strategy on cooperation between higher-education institutions, industry and local factors, the awareness of the necessity for mutual cooperation in order to create conditions for the creation of knowledge based society grew nevertheless.

The beginning of geographical higher education in Slovenia reaches back to the creation of the Department of Geography at the Faculty of Arts of the University of Ljubljana which was 
established in 1919. The Department developed all traditional stages of geography studies: university degrees, masters' degrees and doctoral studies. The Department also offered their resources to support development of geographical science at the University of Maribor and the University of Primorska. Numerous geographers found their employment opportunities with public institutions, research institutes, development institutes and educational institutions.

Scientific and research work is linked to study programmes and is also subject-matter linked to studying the Slovenian space. The newly formed guidelines in scientific research in the European Union pose new challenges and new opportunities for researchers. These are the reasons why in geography less attention has to be paid merely to scientific geographical research and more to the defined research areas which will have to be more closely linked to the supplementary areas and to interdisciplinary approach. In future, similar to the situation in the area of education, mutual cooperation between researchers and groups of researchers will have to be encouraged, along with greater mobility between disciplines, sectors and research environments.

(Translated by Alenka Drame) 